\title{
https://doi.org/10.48009/2_iis_2005_190-196 \\ EFFECT OF UNIT COST ON ACQUISITION OF TECHNOLOGY IN NIGERIA'S OIL EXPLORATION AND PRODUCTION INDUSTRY
}

\author{
Dr. Ewuuk Lomo-David, North Carolina A\&T State University, lomoe@ncat.edu \\ Dr. Amijaan B. Ikuru, Shell Petroleum Development Company of Nigeria Limited
}

\begin{abstract}
Companies have always used unit cost to help them determine their profitability. In this study, we examined the relationship of unit cost (total cost/output) to the formulation of product and process technology development strategies in Nigeria's oil industry. Ten major energy and petroleum companies participated in the study. Although we could not manipulate the unit cost and technologies deployed so as to infer causation, our study has led to an improvement in the understanding of factors such as the risk and cost of the technology and the articles of agreement between the Nigerian National Petroleum Corporation and the operating companies. These factors seem to drive the formulation of technology strategies in Nigeria's oil industry.
\end{abstract}

Keywords: Nigeria's Oil Industry, Exploration and Production companies, Unit cost, technology development strategies.

\section{INTRODUCTION}

Appropriate technology and political stability are vital for the growth and vitality of any nation's economy. The presence of appropriate technology contributes to the operations of organizations while the lack of it leads to the poor performance of organizations in the vital sectors of the Nigerian economy [5]. The lack of technology constrains the implementation of corporate strategies and policies, slows growth, and minimizes profit. Nigeria's almost total dependence on imported goods and services is attributable to the lack of technology in the manufacturing sector of its economy. These technological impediments experienced in Nigeria's manufacturing firms do not seem to affect the oil industry; as a result, Nigeria's oil industry has remained internationally competitive. This is evident in the fact that Nigeria's oil industry today contributes more than 90 percent of Nigeria's Gross Domestic Product (GDP). In the 1950s it made a paltry 2 percent contribution.

An important determinant of national advantage in an industry is the presence in that nation of supplier industries or related industries that are internationally competitive [10]. If this assertion is right, the interrelationship between the oil industry and the manufacturing sector ought to have driven Nigeria's manufacturing sector into international competitiveness. Because this has not been so in Nigeria, we investigated technology strategies of firms in Nigeria's oil Exploration and Production [EP] industry. While strategy is an organization's plans for competitive advantage, technology strategy is the deployment of technology for competitive advantage with primary focus on the product line, the production process and competencies. This plan exists in all organizations, whether explicitly formulated or tacitly contrived [8]. Our interest in this study is to categorize these plans and to identify variables influencing their formulation. The seven factors that could have causal relationships with strategies are: price of product, unit cost, market share, government activities, sources of technologies, research and development spending, and 
technological skills. The current study specifically explores the effect of unit cost on the formulation of technology strategies.

\section{LITERATURE}

Unit cost is an important measure of E\&P companies' excellence because it is a useful tool for negotiating new contracts with countries in joint venture or production sharing contract situations. Investors in E\&P business employ unit cost as a measure of the health of their organizations. Holding all variables constant, including the price of oil, the profitability of a firm would depend on its cost; i.e.; the higher the cost, the lower the profitability and therefore the less attractive the company will be to investors. Because profit is a major source of investment for growth and survival of organizations E\&P companies monitor their unit exploration or discovery cost (also termed the unit finding cost), unit development or facilities cost and unit operations or production cost. Technology could affect any of these unit costs. Some novel value adding technologies and benefits are 2 percent improvement in uptime of facilities through loss management, 5 to 10 percent additional production from gas lifted fields, $10-25$ percent production improvement from fields less well managed [2].

Most of these technologies relate to the innovative employment of information technology in E\&P business for data acquisition, analysis, and transfer, and in actual drilling operations. Some of these technologies include wireless or satellite communication to allow data acquisition, simulations and optimization techniques and commercial software; web enabled monitoring and control, and data management systems which can integrate production data with business and commercial systems, and the supply chain.

Westgard [11] recommended the level three multilateral well completion technologies as a performance improvement measure in the E\&P industry. By using this technology British Petroleum (BP) and Phillips Petroleum achieved substantial unit cost reduction, lowered multilateral well costs by reducing well bore trips, and increased production from mature fields. The estimated saving was about a third of a million dollars and the production increase was more than 280 percent over that of a conventional well. Similarly, the dual gradient drilling [DGD] technology have led to savings of between 6.5 and 11 percent for wells in the Gulf of Mexico drilled in 2,500 feet water to 22,500 feet depth, and savings of between 29 and 32 percent for wells drilled in 7,000 feet of water to 18,000 feet depth.

Technology therefore, can lead to reduction in unit cost. However, it is yet to be established that the acquisition and deployment of these costs saving technologies would depend on the unit cost position of firms.

In Nigeria's oil industry, government and operators have been very keen on cost reduction. The cost of production is not only exploitative; its current high value could be reduced by using a strategy of indigenization in the vital sectors of the E\&P industry, including the strategic apex of the oil servicing companies [6]. The unit cost of production is derived from dividing the total cost (direct production cost and exploration costs) by the total production for the year in question as stated in the formula below. 
$\mathrm{UC}=\frac{\sum(\text { prod operating expenses } \mathrm{T} 1+\text { Capital investment costs } \mathrm{T} 2)}{\text { Annual production (barrels) }}$

Where: $\mathrm{UC}=$ Unit production cost or production cost per barrel.

$\mathrm{T} 1=$ Production operating expenses $=$ direct production expenses plus administrative expenses as apportioned to production plus custom duties and general rentals, plus other extraordinary /prior year expenses/ incomes.

$\mathrm{T} 2=$ Capital investment costs $=$ Exploration costs plus appraisal drilling costs plus intangible drilling and development costs, plus capital allowances (applicable to production and share of the capital allowances allocated to production).

The margin to be earned by each operator depends on the unit cost. To encourage unit cost efficiency in joint venture operations, a tax inversion clause was included in the memorandum of understanding (MOU), such that the Government take will include a penalty arising from high unit cost. This means that E\&P companies would lose money when their capital cost and operation costs exceed predetermined levels [7].

Arghiri, [1] based on his assumption of constant wages, constant rate of profit and growth in capital, seems to be of the view that investment in new technology would not necessarily lead to improvement in profitability. Investment in new technologies would therefore require a consideration of the impact of the technology on the unit cost position of the company. The concept of total life cycle cost, which includes the initial capitalization cost and the operation and maintenance cost, is an important factor in the choice of technologies to develop.

Ikuru [6] explained that at business and operating companies' levels, E\&P companies formulate technology strategies based on products, processes and competencies as seen in the matrix below.

\begin{tabular}{|l|l|}
\hline $\begin{array}{l}\text { Product technology development strategy } \\
\text { Process technology development strategy } \\
\text { Competency technology development strategy }\end{array}$ & \\
& New technologies \\
\hline $\begin{array}{l}\text { Product technology improvement strategy } \\
\text { Process technology improvement strategy } \\
\text { Competency technology improvement strategy }\end{array}$ & Existing technologies \\
& \\
\hline
\end{tabular}

A product technology development strategy is formulated when over a period; a discernible pattern of actions could be observed which tends to favour the allocation of resources for the acquisition and deployment of new product technologies, such as technologies used in exploration, petroleum engineering and drilling. Product technology is developed when relative to the existing technologies in the organization; the decision makers consciously acquired and deployed a new technology. On the other hand, product technology is improved, when an 
existing product technology is innovatively improved, such as, when horizontal drilling is utilized in conjunction with the expanded tubular sand screen (ESS).

Process technologies include technologies required for the manufacturing and assembly line of products. For the oil industry, it includes the technology required to process oil and gas, and evacuate it to the terminals. Such process technologies could include those used in flow stations, multiphase pumps, floating product storage and offloading (FPSO), trunk lines, etc.

Competencies technologies include the skills and knowledge base of the organization, which has the personnel as the sole repository, information management system, and any work improvement and management technology acquired and deployed by organizations. Competencies technology is developed when a new personnel, with a new skill or knowledge is employed. Competencies is improved when a personnel is trained either formally or informally.

\section{HYPOTHESIS}

H1: The higher the unit cost the greater the likelihood of formulating technology development strategies.

\section{METHODOLOGY}

Data for this study was acquired through the use of questionnaires and interviews with employees of E\&P companies. Because the companies were reluctant to divulge their unit cost it was impossible to manipulate unit cost to see how the deployment of technologies responded to it. It was also impossible to manipulate technologies to see how it influenced unit cost.

To gather data for the study we requested E\&P companies to rank their unit cost of production on a scale that shows "high", "average" and "low". The number of wells drilled employing new technologies were used as the independent variable because of the difficulty in physically counting the number of new technologies deployed. Employees were also interviewed based on their experiences and activities. The ten E\&P companies that responded, together, accounted for over 97 percent of Nigeria's total oil output. In terms of productivity therefore, we considered that our study covered the entire E\&P industry. To corroborate the responses obtained with the questionnaires and to obviate its limitations we interviewed ten employees each from five of the companies that responded. Where there was paucity in information, we relied on periodicals and annual reports of these companies.

Our burden of proof was to show that firms that had high unit cost formulated technology improvement strategy over and above the logic of technology development and deployment of new technologies. We used Kendall's $\tau$ as the model of proof. We also used simple averages and percentages to rate the responses of the interviewees to the self-completion questionnaire.

\section{FINDINGS}

The analysis of data resulted in Kendall's $\tau=-0.07$, showing that unit cost was not a primary consideration in the logic of allocation of resources for the deployment of technologies. Most of 
the firms interviewed seem to use weighting criteria in the selection of technologies to develop or improve. In the opinion of these companies, these technologies must have undergone a field pilot trial and found to be cost effective. What matters at the technology strategy stage is therefore not the impact of these technologies on unit cost, rather how to contain the risk associated with the failure or success of the implementation process. Firms with high unit cost did not formulate technology development strategies as hypothesized. This result was corroborated by the result from the interview of employees of the E\&P companies. From these results, we are unable to infer causality but are in a position to state that unit cost does not seem to have a controlling influence on the formulation of technology development strategies.

\section{DISCUSSION}

An observation of behaviours and processes of E\&P companies tended to suggest that the risk associated with technology deployment is usually weighed against the cost of acquisition and deployment of technologies. Where the cost of development is high and the risk of failure is high, organizations tended to prefer improvement of their existing technologies over and above the development of new technologies. On the other hand, technologies with a high probability of success, even at high cost could easily be deployed, depending on the effect it would have on the availability of funds for the acquisition and deployment of technologies.

Most of the E\&P companies tended to deploy new technologies as part of new field development projects. Aware of the risk of failure of technology deployment projects, a project manager is usually appointed, outside the normal organization for the field development. Project managers for field development are usually more concerned about the risk of the new technology deployment project leading to cost overruns and delaying the completion schedule of the project. For this reason, operating companies would rather handle the deployment of new technology as a stand-alone project, with a focused delivery team set to deliver the objective of the project. Once the technology pilot/field test is successfully carried out the use of the technology in other fields and projects is treated routinely.

The risk associated with technology deployment could also be in terms of poor construction and maintenance of the facility, which would result in avoidable reworks and lead to substantial cost overruns. For this reason, the selection and deployment of a new technology, irrespective of the cost impact must consider the probability of success of the project, i.e., whether the required competencies are in the team to ensure successful deployment. Where the impact on unit cost is high and the risk low, organizations appear mostly to adopt technology development strategies. High failure and high impact on unit cost tended to impose the choice of developing new technologies and innovatively improving existing technologies. High risk and low impact on cost position tended to support the formulation of technology improvement strategies. These views are summarised on the technology risk-unit cost impact matrix shown in Figure 1. 


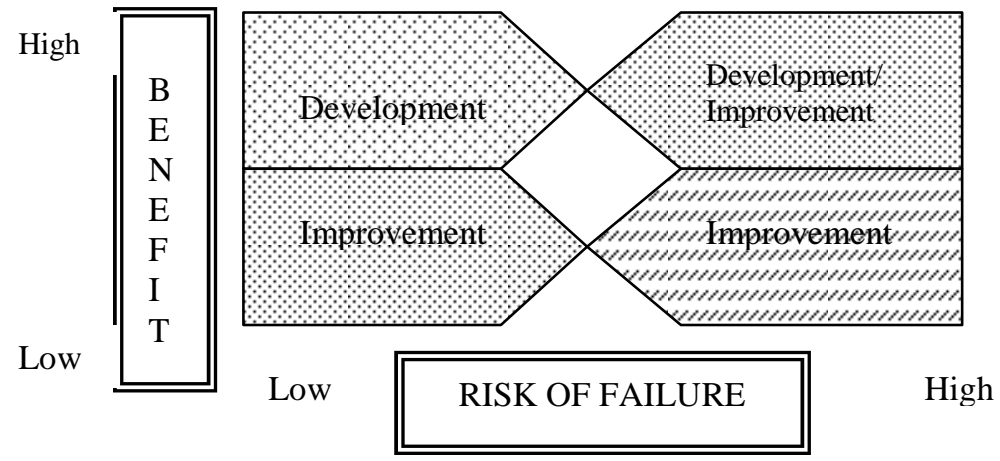

Figure 1. Technology Risk-Benefit Matrix

Multilateral technology for example was not deployed in Nigeria's E\&P industry because of the shortage of technological skills in Nigeria, in spite of its cost benefits. Most E\&P companies rated the risk of failure high due to this absence of skilled personnel at that time.

Technology strategy, Porter [9] argued, should reinforce the competitive advantage a firm is seeking to achieve and sustain. The most important technologies for competitive advantage are those that could skew either cost or differentiation drivers in favour of a company.

The process of identifying projects for investment in E\&P companies requires an evaluation of the profitability of the venture at different price and costs. Where the project meets the decision criteria, with the cost of the technology already considered and included in the project cost, that technology would most likely be developed. If the net present value of future receipts from the investment is however lower than the return from alternative portfolios, then the chances of deploying the technology will be greatly reduced.

The articles of the joint operations agreement (JOA) between the joint venture companies and Nigerian National Petroleum Corporation (NNPC) treat technology, data, proprietary information, and inventions as joint properties of the joint venture partners, which are owned in direct proportion to the participating interest of each partner. According to the JOA, this arrangement assigned to each of the partner, and its affiliates,

"...an irrevocable, non exclusive, license free of royalties or any other charge to use and have used, in its own operations, throughout the world, all of the aforesaid patents and rights including all the technology, technical knowledge, proprietary information, data, inventions and copy rights arising there from."

This implies a free and unmitigated diffusion of technologies. Porter [10] also suggested that the rate of diffusion of technologies is an important factor in determining sustainability of technological lead and therefore investment in technologies. Superior technological skills or cost advantage in performing research and development (R\&D) can be nullified if competitors can easily copy what a firm develops. Joint venture operations appear potentially harmful to the sustainability of a technological lead, as it affords partners, who are also competitors, access to directly observe the products of leaders and reports of jointly patented technologies, usually championed by the operator of the joint venture. This could inform the operator companies' 
preference to carryout research and technology development independently in their home countries, using their group resources. These technologies are then utilized in the joint operations with the payment of appropriate royalties.

\section{CONCLUSION}

The purpose of this study was to determine the effect of unit cost on acquisition of technology in Nigeria's oil exploration and production industry. The result obtained seems to suggest that unit cost does not have a significant influence in the formulation of technology development strategies. This means that the organizations in Nigeria's exploration and production industry that we studied did not consciously formulate their technology development strategies because their existing unit cost was high. Typically and relative to the organizations' project portfolio, projects with the tendency to increase unit cost were dropped at the screening stage. The absence, therefore, of a correlation between the unit cost of the companies and technology development strategies could have been influenced by a plethora of factors. These factors may have been the risk and cost of the technology and the articles of agreement between the Nigerian National Petroleum Corporation and the operating companies.

\section{REFERENCES}

1. Arghiri, E. (1982). Appropriate or underdeveloped technology? New York, NY: John Wiley \& Sons.

2. Arlie, C. (March 2002). Improving performance using new technology and intelligent asset management. World Oil.

3. Chiesa V. M.R. (March 1998). Towards a framework for dynamic technology strategy, Technology Analysis \& Management, 10(1), 111-129.

4. Fubara B. (1986). The Ethics of Nigeria's Proposed Withdrawal from OPEC Journal of Business Ethics, 5(4), 353.

5. Fubara B. (May, 1986). Production Cost Reduction veer indigenized Technologists in the Nigerian Oil Industry, RVB Research Papers, VI(2).

6. Ikuru A. B. (2001). Technology strategies in Nigeria's oil industry, Ph.D. Thesis, Rivers State University of Science and Technology, Port Harcourt.

7. Kemp A. (1987). Petroleum Rent Collection around the World. Halifax Canada Institute for Research on Public Policy, 49.

8. Mintzberg, H. \& Waters, J. A. (1985). Of Strategies Deliberate and Emergent. Strategic Management Journal, 6, 257-272.

9. Porter M. E. (1985). Competitive Advantage Creating and Sustaining Superior Performance, New York: The Free Press.

10. Porter M. E. (1990). The Competitive Advantage of Nations, New York: The Free Press.

11. Westgard D. (June 2002). How operators are benefiting from level 3 multilaterals in Alaska, World Oil, 6, 42-46. 